\title{
Comparative miRNA Expression Profile Analysis of Squamous Cell Carcinoma and Peritumoral Mucosa from the Meso- and Hypopharynx
}

\author{
EVA OROSZ ${ }^{1}$, KATALIN GOMBOS ${ }^{2}$, TAMAS RIEDLING ${ }^{2}$, PRISCILLA AFIAKURUE ${ }^{2}$, \\ ISTVAN KISS $^{3}$, JOZSEF PYTEL ${ }^{1}$, IMRE GERLINGER ${ }^{1}$ and ISTVAN SZANYI ${ }^{1}$ \\ ${ }^{1}$ PTE KK Department of Otorhinolaryngology and Head and Neck Surgery, Pécs, Hungary; \\ ${ }^{2}$ PTE ÁOK Department of Laboratory Medicine, Pécs, Hungary; \\ ${ }^{3}$ PTE ÁOK Department of Public Health Medicine, Pécs, Hungary
}

\begin{abstract}
Background/Aim: The role of microRNAs (miRNA) in carcinogenesis is related to their genomeregulatory function. The aim of the present study was to identify and compare miRNA expression signatures of mesoand hypopharynx squamous cell cancers in consideration of the cancer field hypothesis. Patients and Methods: Thirteen snap-frozen biopsy series of tumors and peritumoral tissues from the meso- and hypopharynx were analyzed regarding their miRNA expression with quantitative real-time polymerase chain reaction ( $q R T-P C R)$. Results: Significant miRNA expression changes of $m i R-21,-27 a,-34 a,-143$ and -146 a were found in peritumoral tissues that were dependent from the tumor location and the distance from the primary tumor site. Conclusion: miRNA expression analysis was found to be appropriate for molecular segregation of tumor location and peritumoral tissue segments, and appears to be a promising marker for cancer field characterization.
\end{abstract}

In Europe, according to the age-standardized rates per 100,000 population, Hungary had the highest estimated incidence, mortality and prevalence in lip, oral cavity and pharyngeal cancers for both sexes. Based on the cancer registerty held by the National Institute of Oncology, in 2010 and 2011 meso- and hypopharyngeal carcinomas counted more than 1,200 cases. The number of diagnosed mesopharyngeal carcinomas in our clinical site has doubled, while hypopharyngeal carcinoma cases have tripled since

This article is freely accessible online.

Correspondence to: Dr. Eva Orosz, Munkácsy utca 2., 7632 Pécs, Hungary. Tel: +36 72507317, e-mail: ev.orosz@gmail.com

Key Words: Head and neck cancer, squamous cell carcinoma, tissue organization field theory, micro-RNA, epigenetics.
1983 (Figures 1 and 2). Incidence of meso- and hypopharyngeal carcinomas is constantly growing, while the rate of mortality is above $50 \%$ due to late-stage recognition. In our clinical practice, malignant cancers of the meso- and hypopharyngeal regions are most specific in the 55-60 age range population, although the appearance of the different pharyngeal carcinomas has been observed in a growing number at younger ages in the past few years. It is important to note that the cancers affecting only one region, having good operability options and a better prognosis are disappearing, while the ones involving more than one region, with aggressive spreading and progressive prognosis are becoming more frequent. Our goal was to find and study a molecular marker that could be used as a predictive and a prognostic tool to complete clinical diagnostics.

In recent years micro-RNAs (miRNA) have been excessively studied. These small, 19-25 base-pair-long RNAs are transcribed from an intra- or intergenic segment of DNA and are not translated into proteins. Matured miRNA binds to a ribonucleotid complex, called RISC (RNA induced silencing complex), and drives the regulation of mRNA translation, either by binding to the target mRNA's 3' UTR (untranslated region) segment, or to 5' UTR or just directly to the ORF (open reading frame). This way translation is blocked or endonucleases are activated causing the degradation of mRNA target $(1,2)$. An estimated $50-60 \%$ of the human genome is regulated by miRNAs. A specific mRNA can be regulated by multiple miRNAs, and a miRNA can modulate translation of more then hundred mRNAs (1). This RNA interference mechanism establishes precise modulation of gene expression, harmonic regulation of cellular functions as cell division, differentiation, apoptosis and intermediary metabolism (3). miRNAs can behave either as oncogenes (oncomirs) or tumor suppressors according to which target mRNA is regulated by them (1). miRNAs can be detected in blood serum, saliva and other body fluids (4- 
9). Cell-free, matured miRNAs - because of their small size - can easily escape from endonuclease activity, this characteristic make them well reproducible and detectable in laboratory experiments (10).

Clinical management of HNSCC is complicated by the high rate of local tumor recurrence or development of a second primary tumor. The development of a recurrent tumor is strongly supported by both the Somatic Mutation Theory and the Tissue Organization Field Theory. Peritumoral tissues which might appear normal on macroscopical and histopathological evaluation can show several genetic and epigenetic alterations: DNA mutations, chromosomal aberrations, genomic instability, changes in DNA methylation and miRNA dysregulation. Our aim was to analyze miRNA expression pattern changes of meso- and hypopharyngeal mucosal tissues surrounding the primary tumors within and beyond the margin of surgical removal, to be able to model the extension field of modified molecular regulatory around tumorous tissue organization $(11,12)$.

\section{Patients and Methods}

Sample collection. Samples of meso- and hypopharynx carcinomas were collected from patients diagnosed and operated on at the Department of Otorhinolaryngology, Head and Neck Surgery of the Clinical Center at University of Pécs. All removed tissue blocks were verified by histopatolocigal examination. During tissue sample collection we followed a standard mapping biopsy strategy and removed small fractions (approx. 0,5-1 $\mathrm{mg}$ ) of mucosal tissues from the tumor edge $(0), 1 \mathrm{~cm}(1)$ and $2 \mathrm{~cm}$ (2) distance from the macroscopic tumor margin and from intact mucosal tissue being at least $3 \mathrm{~cm}$ (3) distance from the tumor margin. During the study 52 tissue samples, originating from 13 patients, were collected. Five patients suffered from hypo- and eight from mesopharnyx carcinoma. On clinicopathological classification tumors were listed into TNM II, III and IV stage squamous cell carcinomas.

RNA isolation. Tissue samples from mapping biopsy were immediately snap-frozen to $-80^{\circ} \mathrm{C}$ following collection until molecular laboratory processing. Sixty $\mu \mathrm{g}$ of tissue sample were homogenized in $150 \mu$ lysis puffer (HighPure miRNA Isolation Kit, catalogue number: 05080576001, Roche, Mannheim, Germany) by using MagNa Lyzer Green Beads (Roche) cheramic beads tubes in MagNA Lyzer (Roche) shaking homogenizer. Total RNA was isolated with downstream application of the High Pure miRNA isolation kit (Roche), following the manufacturer's instructions. RNA quality was checked by nano-drop absorption photometry and only the RNA fractions with $(260 / 280 \mathrm{~nm} \mathrm{~A}>1,9)$ were used for reverse transcription.

cDNA synthesis and RT PCR. Five $\mu \mathrm{g} / \mu \mathrm{l}$ of the RNA templates was used for cDNA synthesis with the Universal cDNA synthesis kit (Quiagen, Woburn, MA, USA), applying the random hexamer priming, included in the kit. cDNA samples were evaluated for miRNA expression in Roche LC480 system (Roche). For miRNA expression analysis specific primers were chosen from the universal miCURY LNA primer set (Exiqon, Vedbaek, Denmark) according to: hsa-miR-21, $-27 a,-34 a,-143,-146 a,-148 a,-155,-221$. Universal miCURY LNA 5S rRNA and U6 snRNA were used as controls for relative quantification. PCR mastermix contained $2 \mu 1$ specific primer mix, $8 \mu \mathrm{l}$ cDNS-template and $10 \mu \mathrm{LC} 480 \mathrm{SYBR}$ Green I Master mix in a total volume of $20 \mu \mathrm{l}$. Amplification was carried out on a $8 \times 12$ plate according to the following design: 6 tumor specific miRNA and two internal controls, that were examined on ten nucleic acid samples with unknown concentrations, on one set of positive samples with known concentrations and against one set of negative controls.

Statistical analysis. Relative quantification results were calculated by Exor4.0 software of LC480 (Roche), using the $\Delta \Delta$-CP method. Calculated relative quantification rates grouped according to tumor and peritumoral tissues were used for further statistical analysis by two tailed two sample T-test, as well as binary logistic regressionusing the software SPSS 21.0.

\section{Results}

During miRNA expression analysis of meso- and hypopharyngeal mapping biopsies from tumor and peritumoral tissues, we found perceptible differences in characterizing the miRNA expression of mucosa surrounding the tumor tissue. Mucosal tissues located $1 \mathrm{~cm}$ away from surgical excision line show only a little difference in expression rate pattern from the tumor itself, while those 2 and $3 \mathrm{~cm}$ away from the tumor differ prominently. The samples taken from $2 \mathrm{~cm}$ and $3 \mathrm{~cm}$ distance from the tumor center shared many similarities in miRNA expression patterns. In the different line segments of peritumoral mucosa a specific miRNA expression pattern has been found. miR$21,-27 \mathrm{a}$ and $-146 \mathrm{a}$ showed a decreasing relative expression rate scaling from the tumor tissues, where their expression is high, towards the peritumoral tissues where their expression is gradually lower according to distance. miR-34a and -143 was found to have similar but inverse expression pattern being the lowest in the tumor and higher in the tumor surrounding tissues. We could not observe such expression changes according to miR-148a, -155 and 221 (Figure 3).

Analysing the miRNA expression reflected to the global expression measured, in cancer cells miR-21, miR-27a, miR221 give nearly $50 \%$ of the cells' total miRNA expression. This number is barely $15 \%$ in cells localized in tissues, which can be found outermost from the tumor tissue. While miR-34a and miR-143 show exactly the opposite; their expression rates are below $10 \%$ in tumor tissue, and growing up step by step to $40 \%$ as we are going further from the tumor. Mucosa being $1 \mathrm{~cm}$ far from surgical excision line shows little difference from the tumor itself in the expression rate referred on each other, while in the distances of 2 and $3 \mathrm{~cm}$ these rates differ prominently. Sample from $2 \mathrm{~cm}$ presents miRNA expression pattern similarities with intact mucosa in the distance of $3 \mathrm{~cm}$. Expression differences are the greatest between the intact mucosa from $3 \mathrm{~cm}$ and the tumor (Figure 4). 


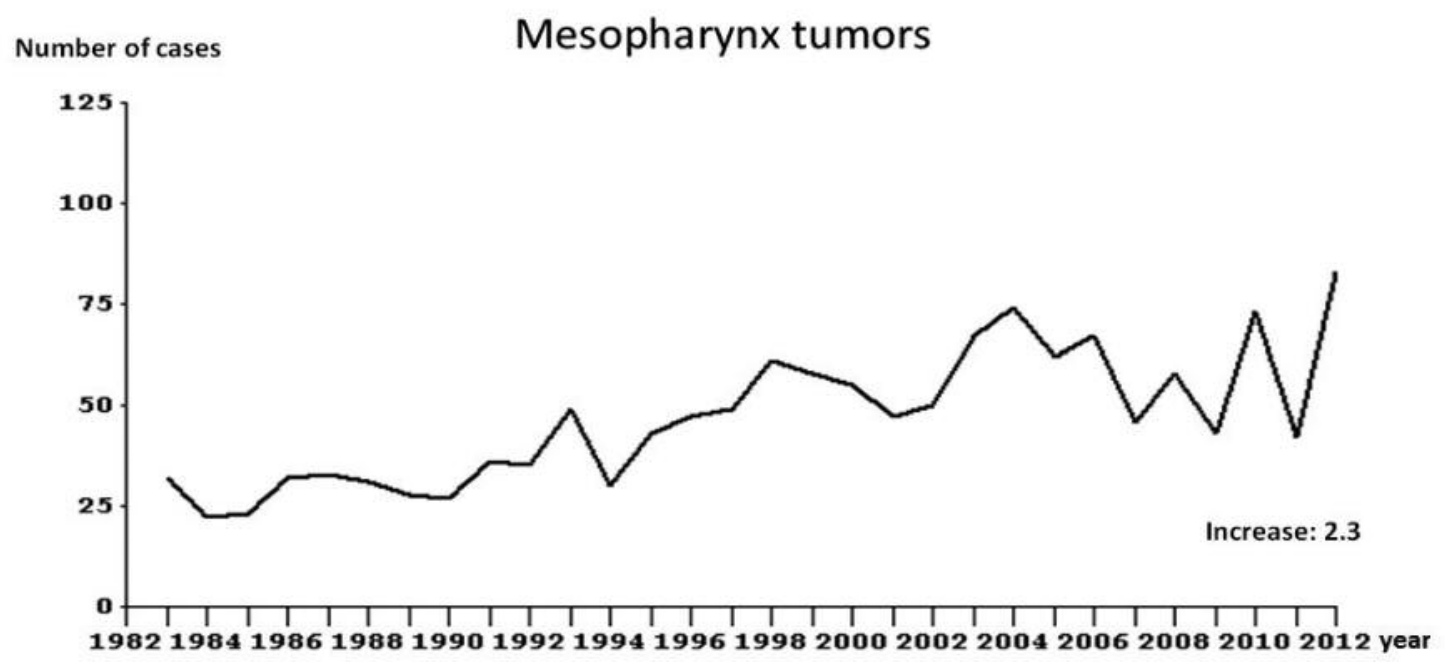

Figure 1. Number of malignant mesopharyngeal tumors in the Department of Otorhinolaryngology and Head and Neck Surgery, Pécs, Hungary between 1983-2012.

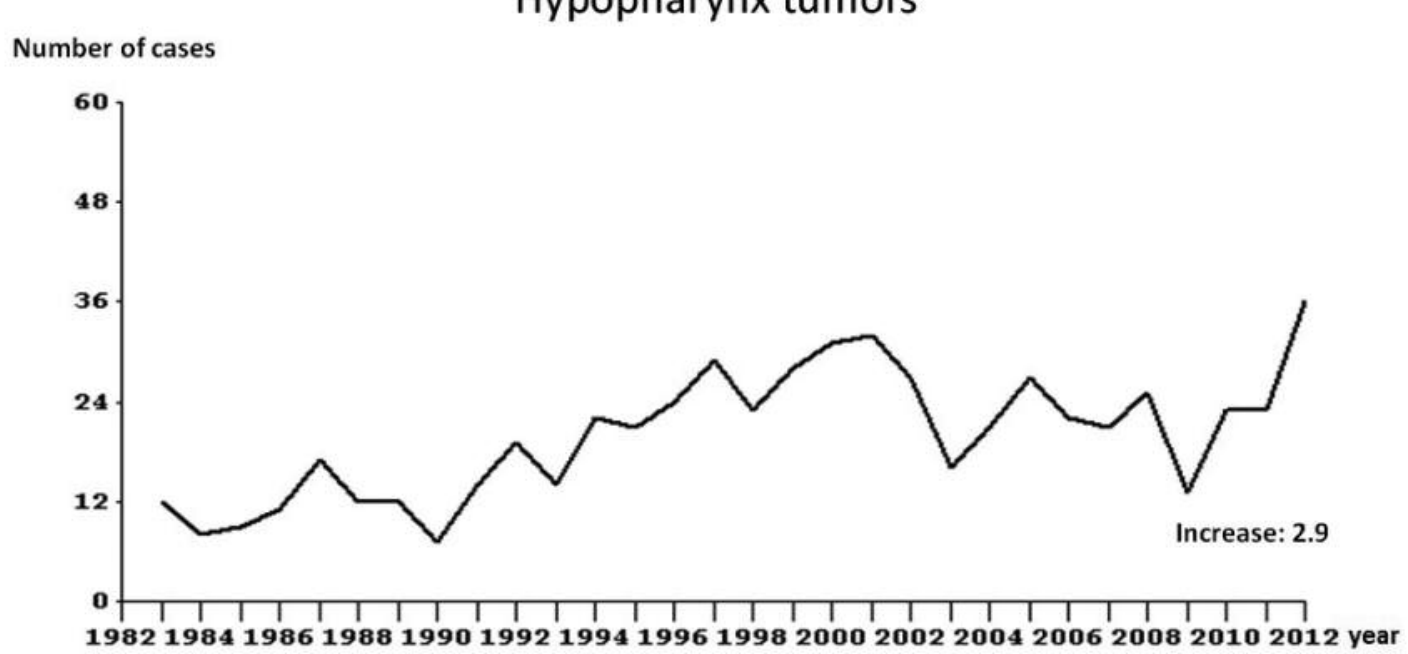

Figure 2. Number of malignant hypopharyngeal tumors in the Department of Otorhinolaryngology and Head and Neck Surgery, Pécs, Hungary between 1983-2012.

Tumor and peritumoral samples of meso- and hypopharynx location showed significantly different miRNA expression rates on binary logistic regression analysis according to miR-21, miR-143, miR-155 and miR-221. In samples from hypopharynx miR-21, 143 and 155 have shown significantly higher expression rates, while expression of miR-221 was detectable solely in samples collected from the mesopharynx $(p<0.05)$.

Study of tumor and peritumoral tissue samples - as in hypo- so in mesopharynx -, tumor and microscopically-intact tissue from $1 \mathrm{~cm}$ showed that they are both epigenetically highly similar (Figures 5 and 6).

\section{Discussion}

Carcinogenesis of oral, laryngeal, meso- and hypopharyngeal squamous cell carcinomas are often described by the cancer field or as we nowadays call it, tissue organization field theory (13-14). This theory states that; the enviromental factors that can initiate tumor development, and the factors, defining individual sensibility can make characteristic changes genomically in the phenotypically-intact mucosa cells. Precursor lesions, primary tumors, recurrent tumors or even a second primary tumor can develop on this genetically or epigenetically 


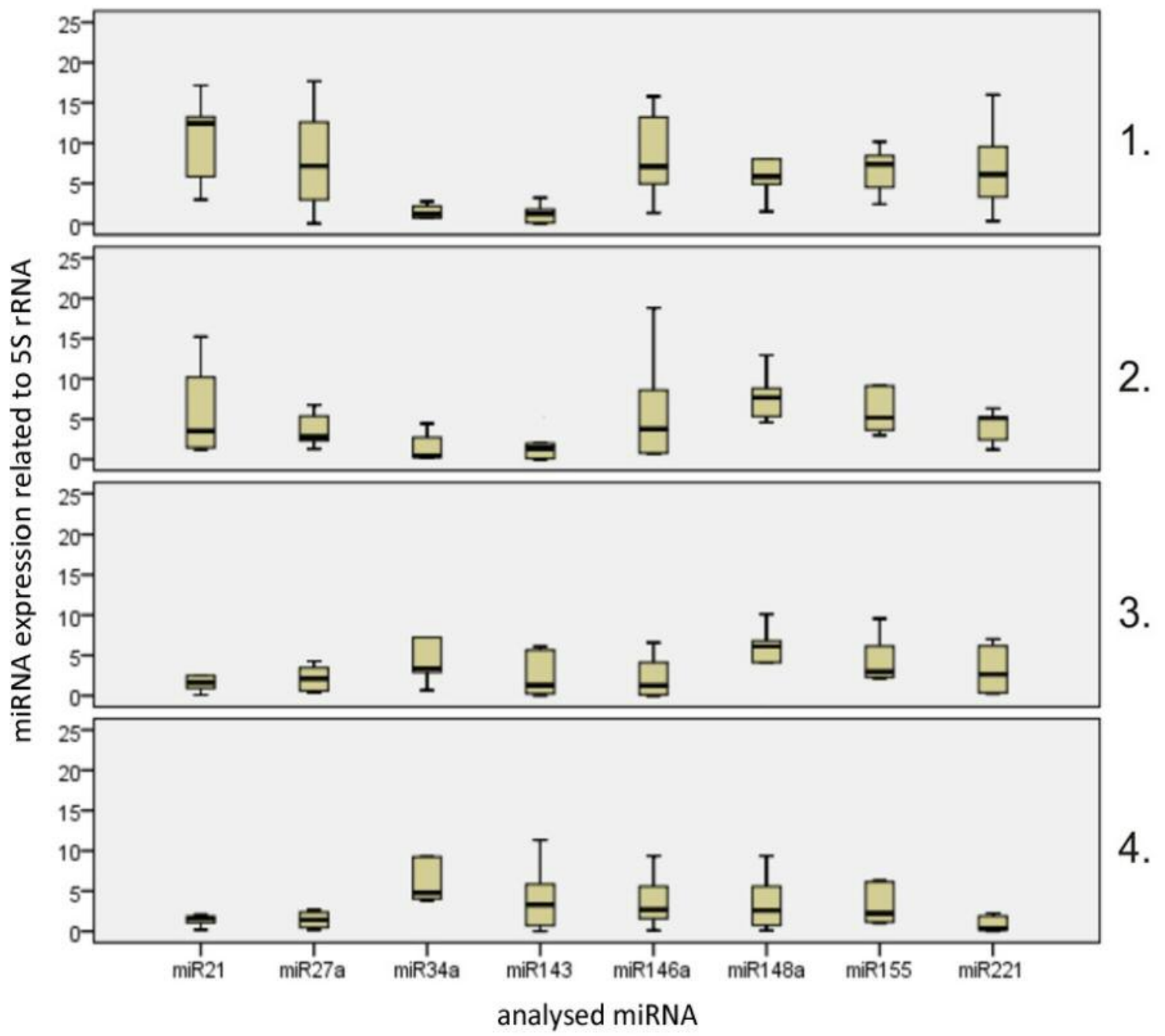

Figure 3. The standard mapping biopsy - 1: tumor biopsy, 2:1 cm 3:2 cm, 4:3 cm distance from the macroscopic tumor margin in the normal тисова.

changed tissue organization field (Figure 7). This theory can explain the clinical features of these tumors such as rapid progression, high recurrence rates, occurrence of second primary tumors at a notably high rate.

miRNAs are defined by individual genetics, but they also play an important role as morphostatic factors on the epigenetic level and they have been proven to be promising in the molecular characterisation of numerous type of cancers (14-16). We found interesting and characteristic differences between miRNA expression rate changes in meso- and hypopharyngeal tumors and peritumoral, macroscopically -intact tissues. We took the advantage of these stable and well reproducible molecules to identify and describe the cancer field, which clearly showed correlation to the changes in the miRNA expression patterns.
miR-21 was found to be statistically significantly elevated in all peritumoral tissues compared to $3-\mathrm{cm}$ distant mucosa. Previous studies have already proven the role of miR-21 in the modified regulation of p53-dependent apoptosis and cellcyle arrest in oral squamo-cellular carcinomas (17-22). In our study, miR-21 showed a significantly elevated expression rate in meso- and hypopharyngeal carcinomas. This expression rate was lowered in intact tissues around the mesopharyngeal carcinomas, while in hypopharyngeal carcinomas this rate was found to be significantly lower $(3 \mathrm{~cm})$ from the tumor itself. Logistic regeression analysis revealed that in hypopharyngeal carcinomas miR-21 expression rates were significantly higher than in mesopharyngeal carcinomas.

miR-34a and miR-143 have been shown to have tumorsuppressor activities. They can block those proteins and their 


\section{tumor}

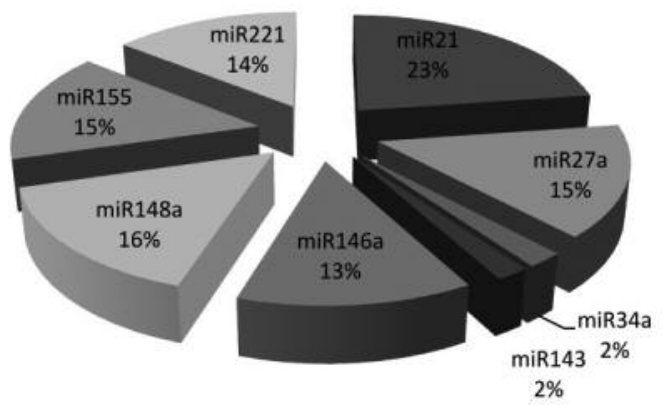

$2 \mathrm{~cm}$

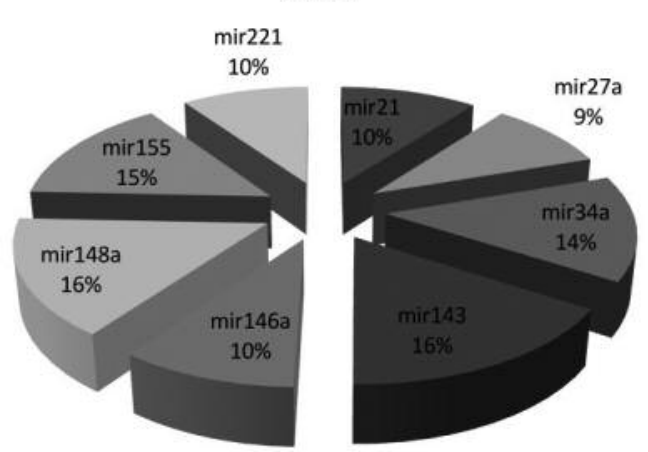

$1 \mathrm{~cm}$
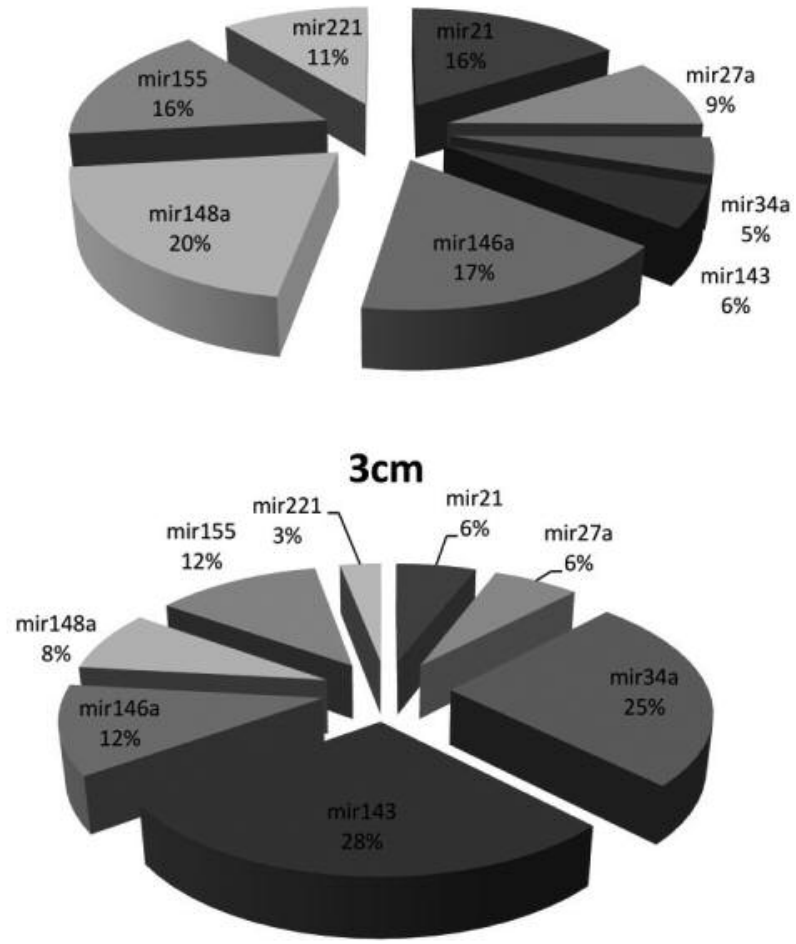

Figure 4. miRNA expression related to their global expression in the tumor and $1 \mathrm{~cm}, 2 \mathrm{~cm}, 3 \mathrm{~cm}$ distance from the tumor.

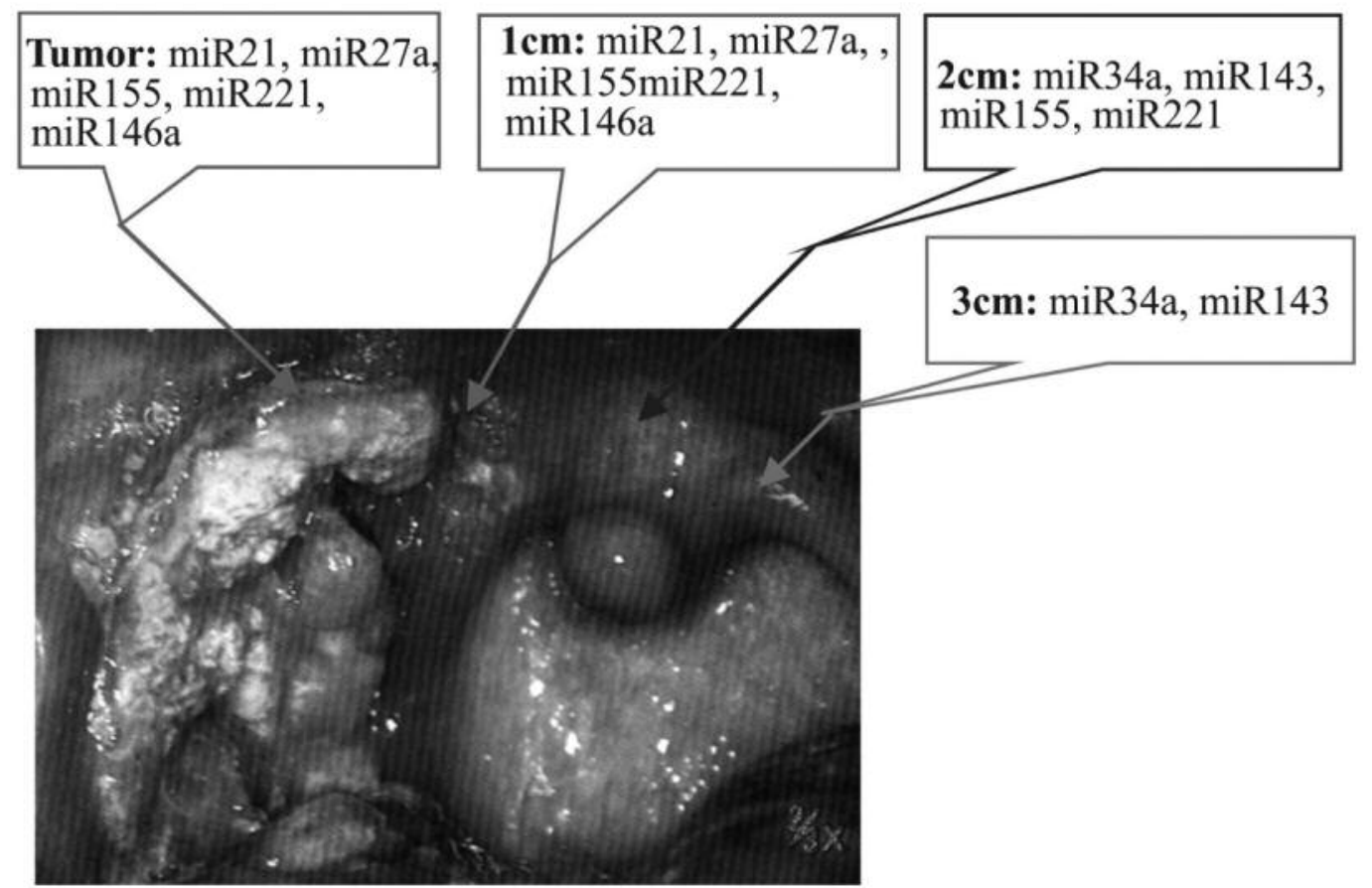

Figure 5. Mesopharyngeal carcinoma and peritumoral tissue (Photograph is published with the written permission of Orvosi Hetilap). 


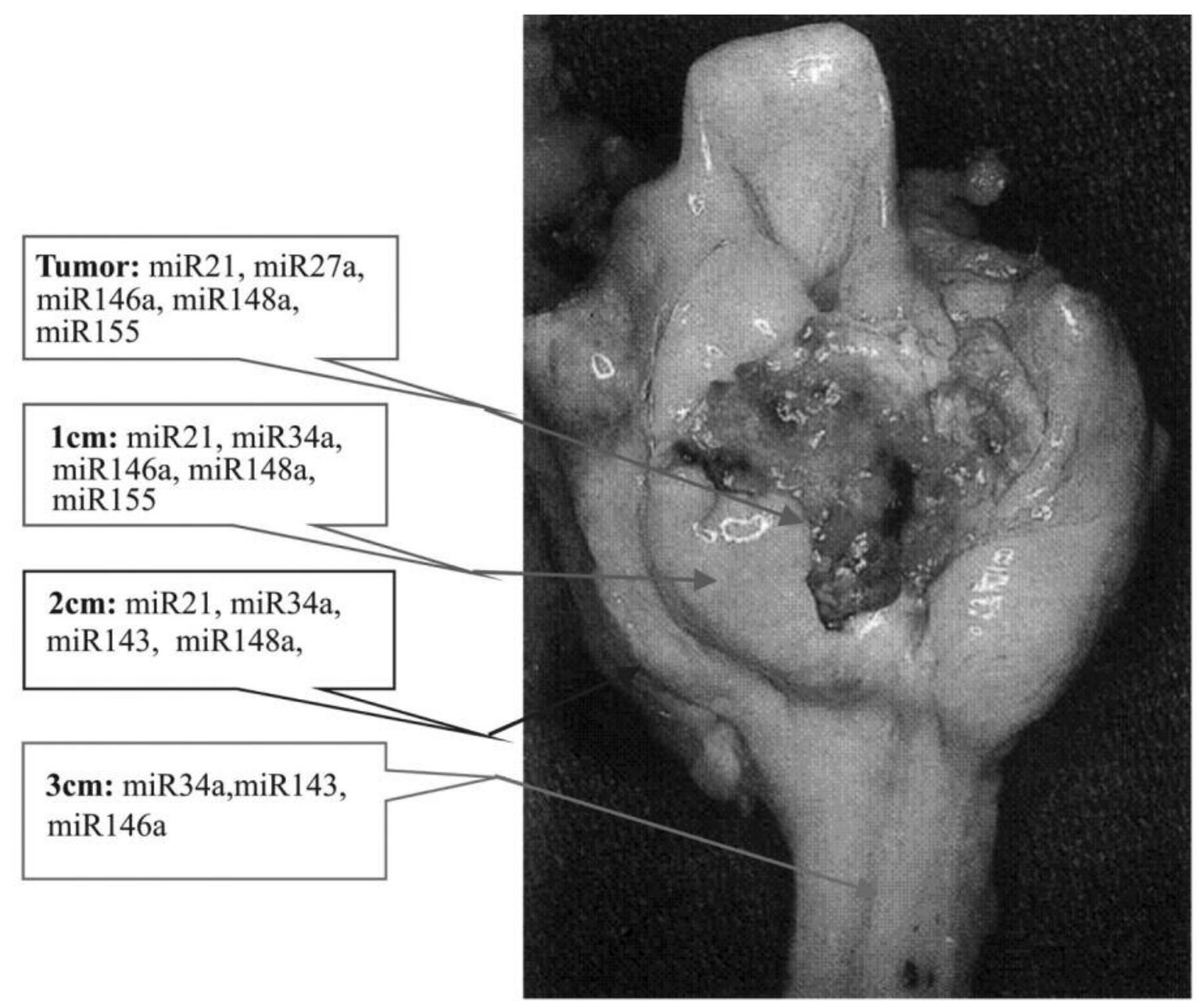

Figure 6. Hypopharyngeal carcinoma and peritumoral tissue (Photograph is published with the written permission of Orvosi Hetilap).

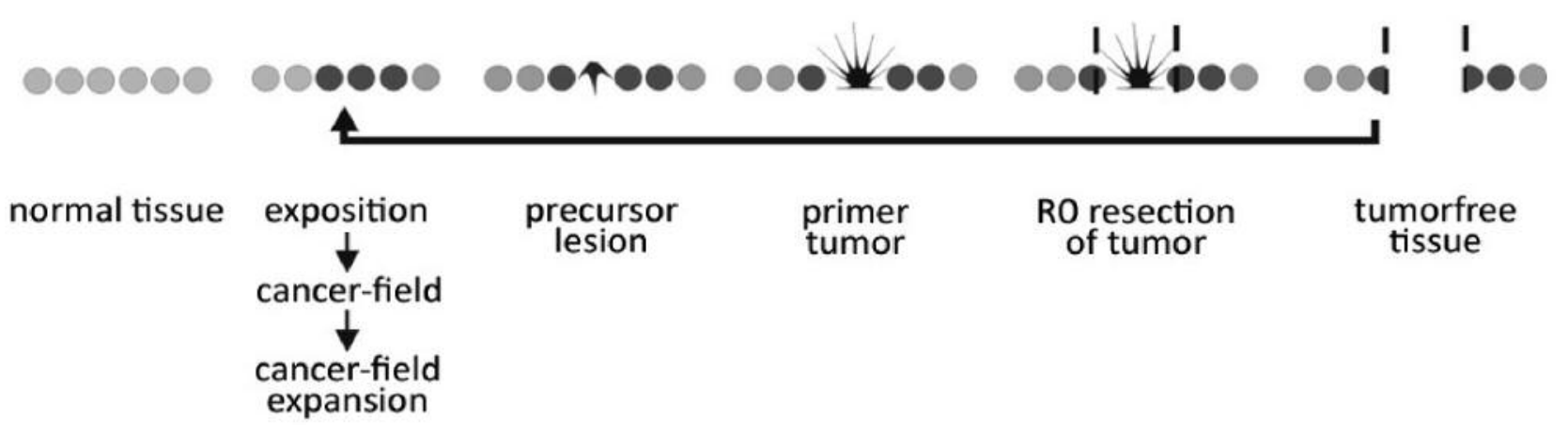

Figure 7. Tissue organization field theory. 
translations, which play important roles in tumor cell proliferation and neoangiogenesis. Their lowered expression rates were identified in HPV associated head and neck cancers (23-28). In our study these miRNAs also showed lowered expression rates. In mesopharyngeal carcinomas these miRNAs were found 2 and $3 \mathrm{~cm}$ from the tumor, while in hypopharyngeal ones miR-34a could be detected in tissues just $1 \mathrm{~cm}$ from the tumor. The loss of miR-34a's expression rate in these tumors is strongly associated with the tumor phenotype. miR-146a and miR-148a are effective blockers of promoter-specific repressors, that play a key role in NF-kB (nuclear factor-kappa B) anti-apoptotic signaling pathway $(29,30)$. These miRNAs play an important role at those signaling points which are shared by both the inflammatory and carcinogenetic pathways. In our study we found both miRNAs' expression characteristic of hypophyrangeal carcinomas. These rates were also observed in the peritumoral tissues and even areas further way from the tumors.

miR-155 has been identified in laryngeal squamous cell carcinomas and can be seen to promote tumor invasion (3133). In our study miR-155 has shown significant expression rates in tumors, and could be also seen in tissues $(2 \mathrm{~cm})$ away from the tumor.

miR-221 was seen in correlation to cancers with bad prognosis and the estimated stage of invasion $(22,34,35)$. In our research we found that miR-221 was the characteristic miRNA in mesopharyngeal carcinomas and in their peritumoral tissues, this miRNA could not be detected in hypopharyngeal carcinomas. it is possible, that in the hypopharynx a variant miRNA with a different nucleotid sequence matures, which we were not able to efficiently amplify by our specific primer sequences. Our further studies will focus on this miRNA to throw more light on this difference.

miR-27a is one of the least studied miRNAs in the literature $(36,37)$. During our research we found that this miRNA showed very similar behavior both in meso- and hypopharyngeal carcinomas as miR-21.

The site-specific comparison of meso- and hypopharyngeal samples mostly resulted in finding the presence of miR-221, and the differences between miR-21, -143, -155 expression rates. miR-21, -143 and -155 markers showed higher expression rates in hypopharyngeal squamous cell carcinomas, while the rate of miR-221 was significantly higher in mesopharyngeal ones. The difference in life style could be a possible explanation to this.

We observed that in miRNA expression rates, some characteristic patterns have been found to be common in tumor tissues, and in the intact mucosa at varying distances from the tumor. We have also found identical profiles and some features which distinguish meso- and hypopharyngeal carcinomas on miRNA expression level. Analysis of miRNA expression signatures was an efficient method to segregate tumor locations and peritumoral tissues. miRNA profile analysis is a promising marker for cancer field characterization. Future application of this method could enable early detection of the disturbed epigenetic regulation in peritumoral tissue fields showing unchanged macroscopic appearance that can be helpful in molecular diagnostics, prognostics and cancer risk assessment (38).

\section{Acknowledgements}

This work was supported by: Research Found of Pécs University Faculty of Medicine KA-2016-19 and the European Union and the State of Hungary, co-financed by the European Social Fund in the framework of TÁMOP 4.2.4.A/2-11-1-2012-0001 'National Excellence Program'. Proposal number: A2-ACSJD-13-0349.

We would like to thank Tamas Toth for his assistance provided by the editing of the figures.

\section{References}

1 Gőcze K, Gombos K, Pajkos G, Magda I, Ember Á, Juhász K, Patczai B and Ember I: Impact of microRNAs on molecular epidemiology [Mikro-RNS-ek jelentősége a molekuláris epidemiológiában]. Orv Hetil 152: 633-641, 2011.

2 Tömböl Zs, Szabó P, Rácz K, Tulassay Zs and Igaz P: Relevance of microRNA-s in neoplastic diseases [A mikro-RNS-ek jelentősége daganatos betegségekben]. Orv Hetil 148: 1135$1141,2007$.

3 Wang M, Wang Q and Zhang B: Response of miRNAs and their targets to salt and drought stresses in cotton. Gene 530: 26-32, 2013.

4 Chakrabortty SK, Prakash A, Nechooshtan G, Hearn S and Gingeras TR: Extracellular vesicle-mediated transfer of processed and functional RNY5 RNA. RNA 21: 1966-79, 2015.

5 Gombos K, Horváth R, Szele E, Juhász K, Gocze K, Somlai K, Pajkos G, Ember I and Olasz L: miRNA expression profiles of oral squamous cell carcinomas. Anticancer Res 33: 1511-1517, 2013.

6 Zen K and Zhang CY: Circulating microRNAs: a novel class of biomarkers to diagnose and monitor human cancers. Med Res Rev 32: 326-348, 2012.

7 van Balkom BW, Eisele AS, Pegtel DM, Bervoets S and Verhaar MC: Quantitative and qualitative analysis of small RNAs in human endothelial cells and exosomesprovides insights into localized RNA processing, degradation and sorting. J Extracell Vesicles 4: 26760, 2015.

8 Yeri A, Courtright A, Reiman R, Carlson E, Beecroft T, Janss A, Siniard A, Richholt R, Balak C, Rozowsky J, Kitchen R, Hutchins E, Winarta J, McCoy R, Anastasi M, Kim S, Huentelman M and Van Keuren-Jensen K: Total extracellular small RNA profiles from plasma, saliva, and urine of healthy subjects. Sci Rep 7: 44061, 2017.

9 Fehlmann T, Ludwig N, Backes C, Meese E and Keller A: Distribution of microRNA biomarker candidates in solid tissues and body fluids. RNA Biol 13: 1084-1088, 2016.

10 Lawrie $\mathrm{CH}$, Gal S, Dunlop H M, Pushkaran B, Liggins AP, Pulford K, Banham AH, Pezzella F, Boultwood J, Wainscoat JS, Hatton CS and Harris AL: Detection of elevated levels of tumorassociated microRNAs in serum of patients with diffuse largeBcell lymphoma. Br J Haematol 141: 672-675, 2008. 
11 Braakhuis BJ, Brakenhoff RH and Leemans CR: Second field tumors: a new opportunity for cancer prevention? Oncologist 10 : 493-500, 2005.

12 Braakhuis BJ, LeemansCr and Brakenhoff RH: A genetic progression model of oral cancer: current evidence and clinical implications. J Oral Pathol Med 33: 317-322, 2004.

13 Cognetti DM, Weber RS and Lai SY: Head and neck cancer: an evolving treatment paradigm. Cancer 113: 1911-1932, 2008.

14 Iorio MV and Croce CM: microRNA involvement in human cancer. Carcinogenesis 33: 1126-1133, 2012.

15 Mydlarz WK, Hennessey PT and CalifanoJA: Advances and perspectives in the molecular diagnosis of head and neck cancer. Expert Opin Med Diagn 4: 53-65, 2010.

16 Kaladhar B Reddy: MicroRNA (miRNA) in cancer. Cancer Cell Int 15: 38, 2015.

17 Zhu S, Wu H, Wu F, Nie D, Sheng S and Mo YY: MicroRNA21 targets tumor suppressor genes in invasion and metastasis. Cell Res 18: 350-359, 2008.

18 Boldrup L, Coates PJ, Wahlgren M, Laurell G and Nylander K: Subsite-based alterations in miR-21, miR-125b, and miR-203 in squamous cell carcinoma of the oral cavity and correlation to important target proteins. J Carcinog 11: 18, 2012.

19 Zhang BG, Li JF, Yu BO, Zhu ZG, Liu BY and Yan M: microRNA-21 promotes tumor proliferation and invasion in gastric cancer by targeting PTEN. Oncol Rep 27: 1019-1026, 2012.

20 Mydlarz W, Uemura M, Ahn S, Hennessey P, Chang S, Demokan S, Sun W, Shao C, Bishop J, Krosting J, Mambo E, Westra W, Ha P, Sidransky D and Califano J: Cluster in Is a Gene-Specific Target of microRNA-21 in Head and Neck Squamous Cell Carcinoma. Clin Cancer Res 20: 868-877, 2014.

21 Akagi I, Miyashita M, Ishibashi O, Mishima T, Kikuchi K, Makino H, Nomura T, Hagiwara N, Uchida E and Takizawa T: Relationship between altered expression levels of MIR21, MIR143, MIR145, and MIR205 and clinicopathologic features of esophageal squamous cell carcinoma. Dis Eosophagus 24: 523-530, 2011.

22 Kan X, Sun Y, Lu J, Li M, Wang Y, Li Q, Liu Y, Liu M and Tian L: Coinhibition of miRNA21 and miRNA221 induces apoptosis by enhancing the p53mediated expression of proapoptotic miRNAs in laryngeal squamous cell carcinoma. Mol Med Rep 13: 4315-20, 2016.

23 Wald AI, Hoskins EE, Wells SI, Ferris RL and Khan SA: Human Papilloma virus alters microRNA profiles in squamous cell carcinoma of the head and neck (SCCHN) cell lines. Head Neck 33: 504-512, 2011.

24 Saintigny P, Zhang L, Fan YH, El-Naggar AK, Papadimitrakopoulou VA, Feng L, Lee JJ, Kim ES, Ki Hong W and Mao L: Gene expression profiling predicts the development of oral cancer. Cancer Prev Res 4: 218-229, 2011.

$25 \mathrm{Li} \mathrm{W}, \mathrm{Ma} \mathrm{H}$ and Sun J: microRNA34a/c function as tumor suppressors in Hep2 laryngeal carcinoma cells and may reduce GALNT7 expression. Mol Med Rep 9: 1293-1298, 2014.

26 Zauli G, Voltan R, di Iasio MG, Bosco R, Melloni E, Sana ME and Secchiero P: miR-34a induces the downregulation of both E2F1 and B-Myb oncogenes in leukemic cells. Clin Cancer Res 17: 2712-2724, 2011.
27 Wu D, Huang P, Wang L, Zhou Y, Pan H and Qu P: MicroRNA143 inhibits cell migration and invasion by targeting matrix metalloproteinase 13 in prostate cancer. Mol Med Rep 8: 626-630, 2013.

28 Muñoz-Largacha JA, Gower AC, Sridhar P, Deshpande A, O'Hara CJ, Yamada E, Godfrey TE, Fernando HC and Litle VR: miRNA profiling of primary lung and head and neck squamous cell carcinomas: Addressing a diagnostic dilemma. J Thorac Cardiovasc Surg doi: 10.1016/j.jtcvs.2017.02.071, 2017. [Epub ahead of print]

29 Volinia S, Calin GA, Liu CG, Ambs S, Cimmino A, Petrocca F, Visone R, Iorio M, Roldo C, Ferracin M, Prueitt RL, Yanaihara N, Lanza G, Scarpa A, Vecchione A, Negrini M, Harris CC and Croce CM: A microRNA expression signature of human solid tumors defines cancer gene targets. Proc Natl Acad Sci 103: 2257-2261, 2006.

30 Motsch N, Pfuhl T, Mrazek J, Barth S and Grässer FA: EpsteinBarr virus-encoded latent membrane protein 1 (LMP1) induces the expression of the cellular microRNA miR-146a. RNA Biol 4: 131-137, 2007.

31 Ramdas L, Giri U, Ashorn C, Coombes KR, El-Naggar A, Ang KK and Story MD: miRNA expression profiles in head and neck squamous cell carcinoma and adjacent normal tissue. Head Neck 31: 642-654, 2009.

32 Jian-ling Wang, Xin Wang, Dong Yang and Wen-jie Shi: The Expression of MicroRNA-155 in Plasma and Tissue Is Matched in Human Laryngeal Squamous Cell Carcinoma. Yonsei Med J 57: 298-305, 2016.

33 Liu J, Mao Q, Liu Y, Hao X, Zhang S and Zhang J: Analysis of miR-205 and miR-155 expression in the blood of breast cancer patients. Chin J Cancer Res 25: 46-54, 2013.

34 Garofalo M, Di Leva G, Romano G, Nuovo G, Suh SS, Ngankeu A, Taccioli C, Pichiorri F, Alder H, Secchiero P, Gasparini P, Gonelli A, Costinean S, Acunzo M, Condorelli G and Croce CM: miR-221\&222 regulate TRAIL resistance and enhance tumor igenicity through PTEN and TIMP3 down-regulation. Cancer Cell 16: 498-509, 2009.

35 Wang J, Liu S, Sun GP, Wang F, Zou YF, Jiao Y, Ning J and Xu J: Prognostic significance of microRNA-221/222 expression in cancers: evidence from 1,204 subjects. Int J Biol Markers 29: 129-141, 2014.

36 Gao Y, Li BD and Liu YG: Effect of miR27a on proliferation and invasion in colonic cancer cells. Asian Pac J Cancer Prev 14: 4675-4678, 2013.

37 Liu W, Qian K, Wei X, Deng H, Zhao B, Chen Q, Zhang J and Liu H: miR27a promotes proliferation, migration, and invasion of colorectal cancer by targeting FAM172A and acts as a diagnostic and prognostic biomarker. Oncol Rep 37: 3554-3564, 2017.

38 Baker SG: A cancer theory kerfuffle can lead to new lines of research. J Natl Cancer Inst 107: dju405, 2015.

Received April 25, 2017

Revised May 29, 2017

Accepted June 1, 2017 